\title{
Tectonic and magmatic patterns in the Jutulstraumen rift (?) region, East Antarctica, as imaged by high-resolution aeromagnetic data
}

\author{
F. Ferraccioli, P. C. Jones, M. L. Curtis, P. T. Leat, and T. R. Riley \\ British Antarctic Survey, High Cross, Madingley Road, Cambridge CB3 OET, UK
}

(Received March 1, 2004; Revised February 18, 2005; Accepted February 20, 2005)

\begin{abstract}
The Jutulstraumen ice stream in western Dronning Maud Land may conceal a Jurassic continental rift. Delineating the geometry and the magmatic patterns of this inferred glaciated rift in East Antarctica is important to improve our understanding of the regional tectonic and magmatic processes associated with Gondwana break-up. A high-resolution aeromagnetic survey provides new insights over the largely buried tectonic and magmatic patterns of the Jutulstraumen area. Prominent NE-SW oriented aeromagnetic trends are detected over the Jutulstraumen. These trends delineate major inherited structural boundaries, active in Grenvillian (about 1.1 Ga) and Pan-African times (about $500 \mathrm{Ma}$ ), which appear to strongly control the location of the later Jurassic rift. The postulated eastern flank of the rift is marked by a broad positive anomaly over H. U. Sverdrupfjella. Buried Grenvillian age rocks may be the source of the long-wavelength anomaly. However, the higher frequency components correlate with granitoids of late Pan-African age. The inferred western flank of the rift features short-wavelength anomalies over the Borgmassivet and Ahlmannryggen areas, indicating a considerably greater extent of mid-Proterozoic tholeiitic sills than apparent in outcrop. In contrast, aeromagnetic signatures suggest that alkaline plutons, which relate to Jurassic rifting, are restricted to outcrop areas along the eastern rift flank. The prominent magnetic low over the Jutulstraumen indicates either a largely amagmatic rift, or perhaps subglacial sediments within the rift basin.
\end{abstract}

Key words: Aeromagnetic anomalies, rift, Jutulstraumen, East Antarctica.

\section{Introduction}

Aeromagnetic surveys are essential for geological investigations over Antarctica because extensive ice cover often hinders direct observation of key structural and magmatic elements. Consequently, a significant amount of reconnaissance aeromagnetic data have been collected over the Antarctic during the last 40 years and have contributed towards understanding a variety of regional tectonic provinces within the continent (Golynsky et al., 2001; Golynsky et al., 2003). For example, several regional aeromagnetic surveys have imaged tectonic and magmatic patterns concealed beneath glaciated continental rifts of Cenozoic age in West Antarctica (Blankenship et al., 1993; Behrendt et al., 1996; Behrendt, 1999). Regional aeromagnetic investigations have also been successful in delineating Early Paleozoic inherited crustal features along the flanks of the West Antarctic Rift System (Ferraccioli and Bozzo, 1999; Finn et al., 1999; Ferraccioli et al., 2002a, b). Typically aeromagnetic surveys flown in Antarctica over the last decade have flight-line spacing of $5 \mathrm{~km}$. However, higherresolution aeromagnetic surveys are still in an early stage over Antarctica, compared to other continents. Only one high-resolution survey (line spacing $500 \mathrm{~m}$ ) has been flown in West Antarctica for the Cape Roberts Drilling Project (Bozzo et al., 1997). This survey imaged faults and intru-

Copyright (c) The Society of Geomagnetism and Earth, Planetary and Space Sciences (SGEPSS); The Seismological Society of Japan; The Volcanological Society of Japan; The Geodetic Society of Japan; The Japanese Society for Planetary Sciences; TERRAPUB. sions of the Ross Sea Rift margin with unprecedented detail compared to previous regional surveys (Ferraccioli and Bozzo, 2003), demonstrating the utility of higher resolution aeromagnetic surveying for rift studies over Antarctica.

We present magnetic anomaly images derived from a high-resolution (1 km line spacing) aeromagnetic survey over the Jutulstraumen rift area, in western Dronning Maud Land (Fig. 1). This high-resolution aeromagnetic survey was part of the "Magmatism as a Monitor of Gondwana break-up" project (MAMOG) of the British Antarctic Survey, which included new geochemical investigations, structural geology, geochronology, and AMS studies over western Dronning Maud Land. By providing new constraints on the magmatic and structural context of the Dronning Maud Land margin, this multi-disciplinary project aims to re-address the mantle processes responsible for the generation of the Karoo Large Igneous Province, and the initial break-up of Gondwana. Previous structural and petrological investigations in western Dronning Maud Land (Fig. 1) indicated that the Jutulstraumen ice stream (Hoyday, 1996) could conceal a branch of a Jurassic-age rift system (Grantham and Hunter, 1991; Grantham, 1996). The inferred rift relates either to "active rifting" processes, involving the mantle plume, which generated the Jurassic Karoo Large Igneous Province in Africa and in Antarctica (Cox, 1992; Riley et al., 2005), or it could represent a "passive rift" unrelated to the plume. In either end-member scenarios, the inferred rift could potentially have exploited an older lithopsheric boundary between an Archean Cra- 


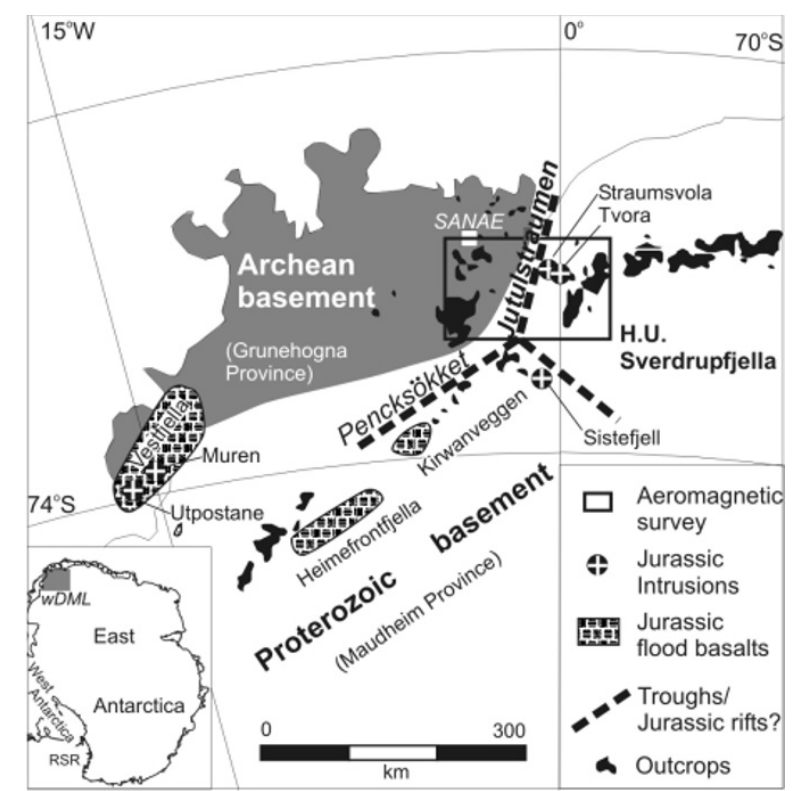

Fig. 1. Major tectonic provinces over the Jutulstraumen and adjacent Pencksökket areas in western Dronning Maud Land (wDML), East Antarctica. Note the topographic troughs in our study area, which have been suggested to be Jurassic rifts (Grantham and Hunter, 1991). Also note the Jurassic flood basalts and the Jurassic intrusions. RSR (see inset) denotes the Cenozoic Ross Sea Rift, part of the West Antarctic Rift System. ton (the Grunehogna Province) and a Proterozoic to Early Paleozoic mobile belt known as the Maudheim Province (Groenwald et al., 1991). The location of faults bounding the inferred Jurassic rift and their relation to inherited lithospheric boundaries, remained however poorly constrained prior to our aeromagnetic study. Nevertheless, Grantham and Hunter (1991) suggested that prior to Gondwana breakup (Martin and Hartnady, 1986; Cox, 1992; Tikku et al., 2002; Jokat et al., 2003) the inferred Jutulstraumen rift could have been connected to the western branch of the East African Rift System (Fig. 2). We show that high-resolution aeromagnetics provides a powerful geophysical tool to image the extent of the subglacial rift in East Antarctica.

A compilation of previous regional Russian aeromagnetic data over western Dronning Maud Land imaged the Pencksökket branch (Fig. 1) of the inferred Jurassic rift system, while the coverage over the Jutulstraumen was less complete (Golynsky et al., 2000a, b; Golynsky et al., 2002). Our magnetic anomaly images provide a new and more detailed means to explore the tectonic and the magmatic patterns further north over the Jutulstraumen rift. These images also allow us to delineate the major inherited structures, within the Maudheim Province, which controlled the location of the later Jurassic continental rift and played an important role in localising the Jurassic alkaline intrusions.

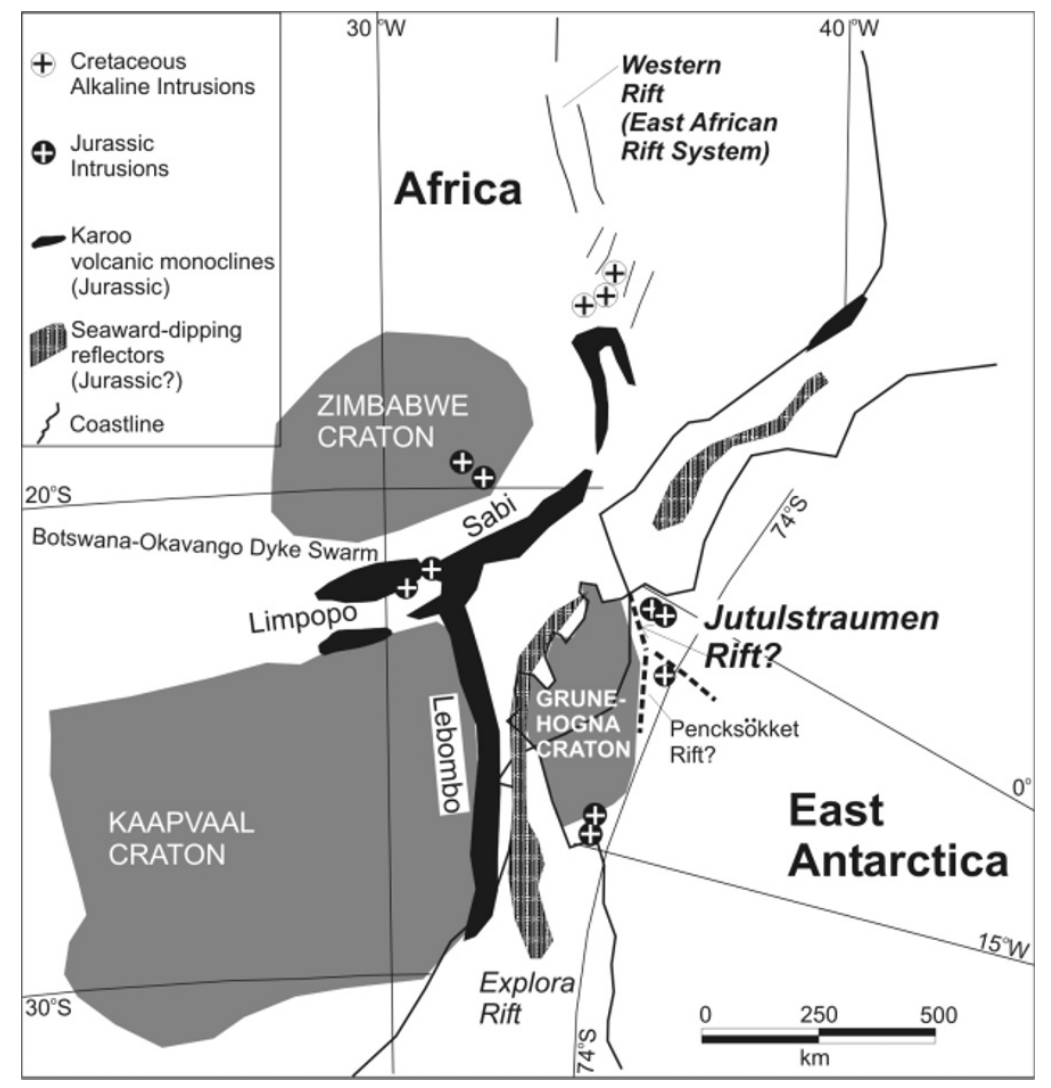

Fig. 2. Cartoon illustrating a possible ultra-tight fit of East Antarctica and south-east Africa in the Jurassic (Cox, 1992). In this configuration, the inferred Jurassic Jutulstraumen rift in East Antarctica is co-linear with the Cretaceous western branch of the East African Rift System, in Africa (Grantham and Hunter 1991). The huge volumes of Jurassic Karoo volcanics in Africa preceded the later formation of oceanic crust in offshore Dronning Maud Land, at about $155 \mathrm{Ma}$, marking the early stages of Gondwana break-up (Jokat et al., 2003). Also note the Jurassic Botswana-Okavango dyke swarm in south Africa (Reeves, 2000; Marsh, 2002). 


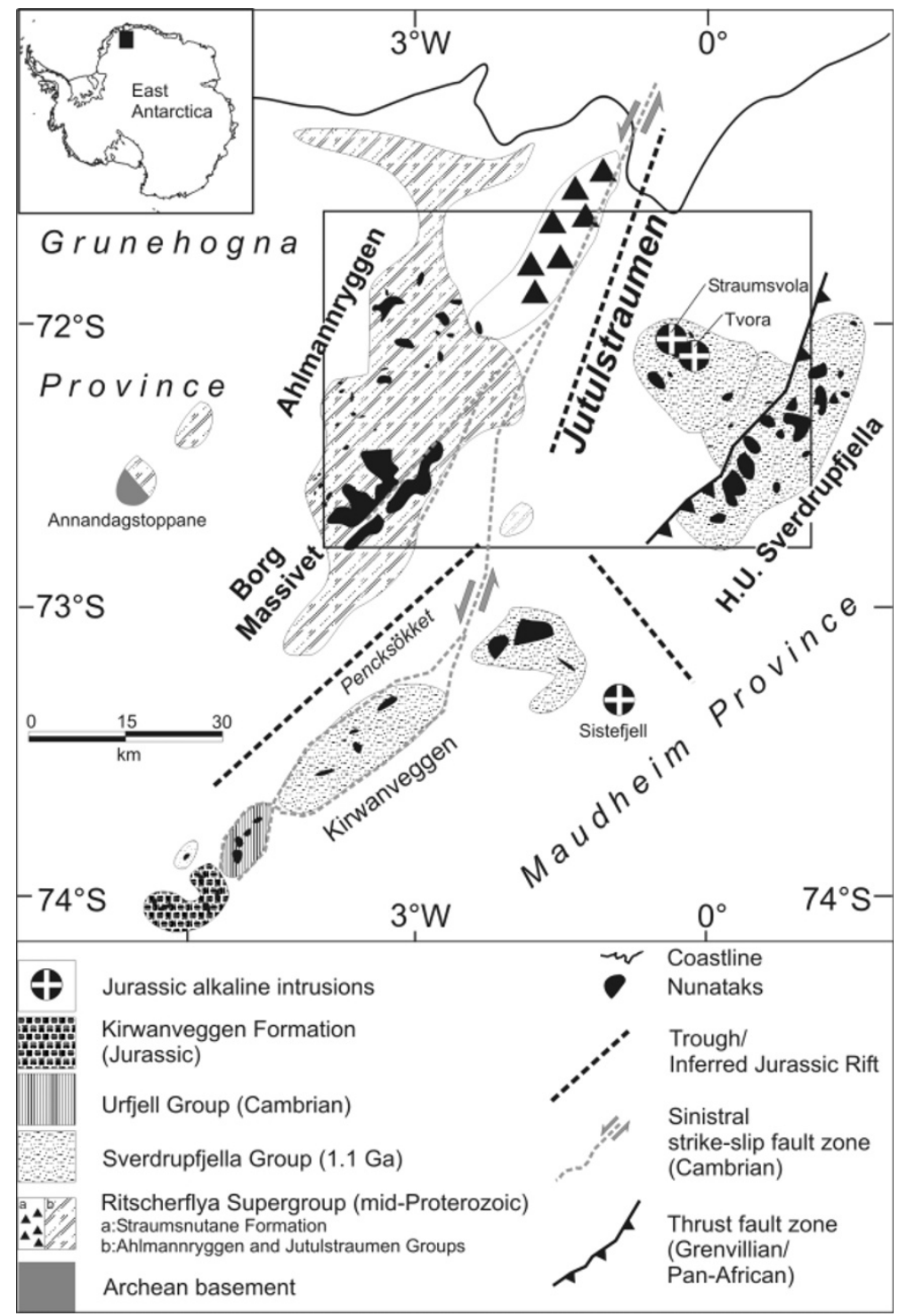

Fig. 3. Simplified geological map for the Jutulstraumen region (modified from Grantham, 1996). The black rectangle shows the area of the high-resolution aeromagnetic survey.

\section{Geological Framework}

The Pencksökket and the Jutulstraumen glaciers may conceal a buried lithospheric boundary between an Archean to mid-Proterozoic cratonic fragment, known as the Grunehogna Province (Fig. 1), and the mid-Proterozoic to Cambrian Maudheim Province (Groenwald et al., 1991; Moyes et al., 1993a; Groenwald et al., 1995). The Archean granites of the Grunehogna Province outcrop in the Annandagstoppane (Fig. 3) area (Barton et al., 1987; Groenwald et al., 1995). The overlying mid-Proterozoic Ritscherflya Supergroup consists of relatively undeformed sedimentary and volcanogenic rocks of the Ahlmannryggen and Jutulstraumen groups (Wolmarans and Kent, 1982). The Ritscherflya Supergroup is intruded by tholeiitic sills and dykes of the Borgmassivet Intrusives (Wolmarans and Kent, 1982). The age of the tholeiites is not well constrained, but lies within the Mid- to Late Proterozoic age range. These tholeiitic rocks may be coeval (Groenwald et al., 1991) with the Umkondo large igneous province of southern Africa (1.1 Ga: Hanson et al., 1998). The Ritscherflya Supergroup also includes the Straumsnutane Formation, consisting of andesitic lava flows with minor pyroclastics and sediments (Wolmarans and Kent, 1982). These $800 \mathrm{Ma}$ (?) andesites are more than $860 \mathrm{~m}$ thick, and close to the western margin of the Jutulstraumen glacier, they appear to be intensely sheared (Wolmarans and Kent, 1982).

Within the Maudheim Province the Sverdrupfjella Group includes two lithostratigraphic assemblages: amphibolite facies calc-alkaline metavolcanic rocks to the west and further to the east granulite facies para- and ortho-gneisses (Grantham et al., 1988; Groenwald et al., 1991, 1995). These Grenvillian age rocks (1.2-1 Ga) were intruded by Pan-African age granites, which include the A-type Brattskarvet suite $(\cong 520 \mathrm{Ma})$ and the S-type, syntectonic

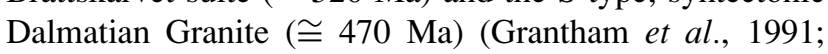
Moyes et al., 1993b).

The structural architecture of H. U. Sverdrupfjella is characterised by thrust faults (Allen, 1991). A major NESW oriented thrust fault (Fig. 3) separates the inferred basement complex from the cover rocks to the east (Allen, 

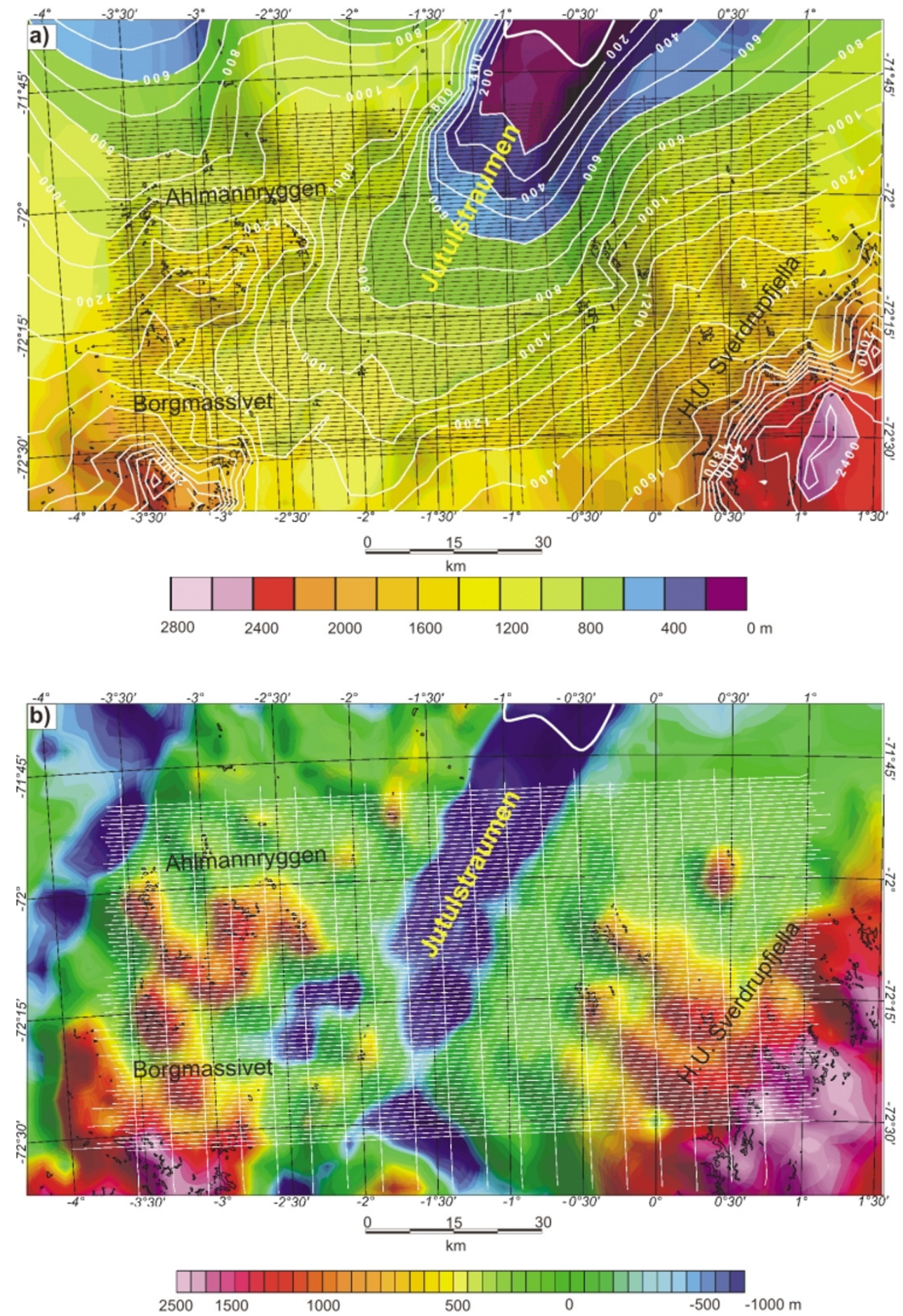

Fig. 4. a) Surface topography of the Jutulstraumen region and high-resolution aeromagnetic survey lines (black). Black outline delineates outcrop, the thick white line is the coastline. Contour lines are shown in white, and contour interval is $100 \mathrm{~m}$; b) Bedrock topography map derived by combining our new airborne and previous radio echo-sounding data over the region (from Ferraccioli et al., in press). Aeromagnetic survey lines are shown in white. Note the deep subglacial trench beneath the Jutulstraumen ice stream, which may represent a rift valley. A sub-parallel rift? valley lies west of our aeromagnetic survey area.

1991). The inferred basement complex is intensely deformed and includes ortho-gneiss and para-gneiss (Allen, 1991). The cover sequence is characterised by abundant para-amphibolites, with rare meta-intrusive rocks. Thrust faults have also been inferred beneath the NW-SE tributary glaciers (Fig. 4(b)), which subdivide the range (Allen, 1991; Grantham et al., 1995). Thrusting may have occurred during both Grenvillian and Pan-African times (Grantham et al., 1995; Groenwald et al., 1995). At $520 \mathrm{Ma}$, the structural boundary between the Grunehonga Province and the Maudheim Province may have been reactivated as a major left-lateral transpressive fault system, possibly also causing the Pan-African age thrusting (Allen, 1991; Perritt and Watkeys, 2003).

Continental flood-basalts of the Jurassic age (Figs. 1 and 2) outcrop in the Kirwanveggen, Heimefrontfjella 


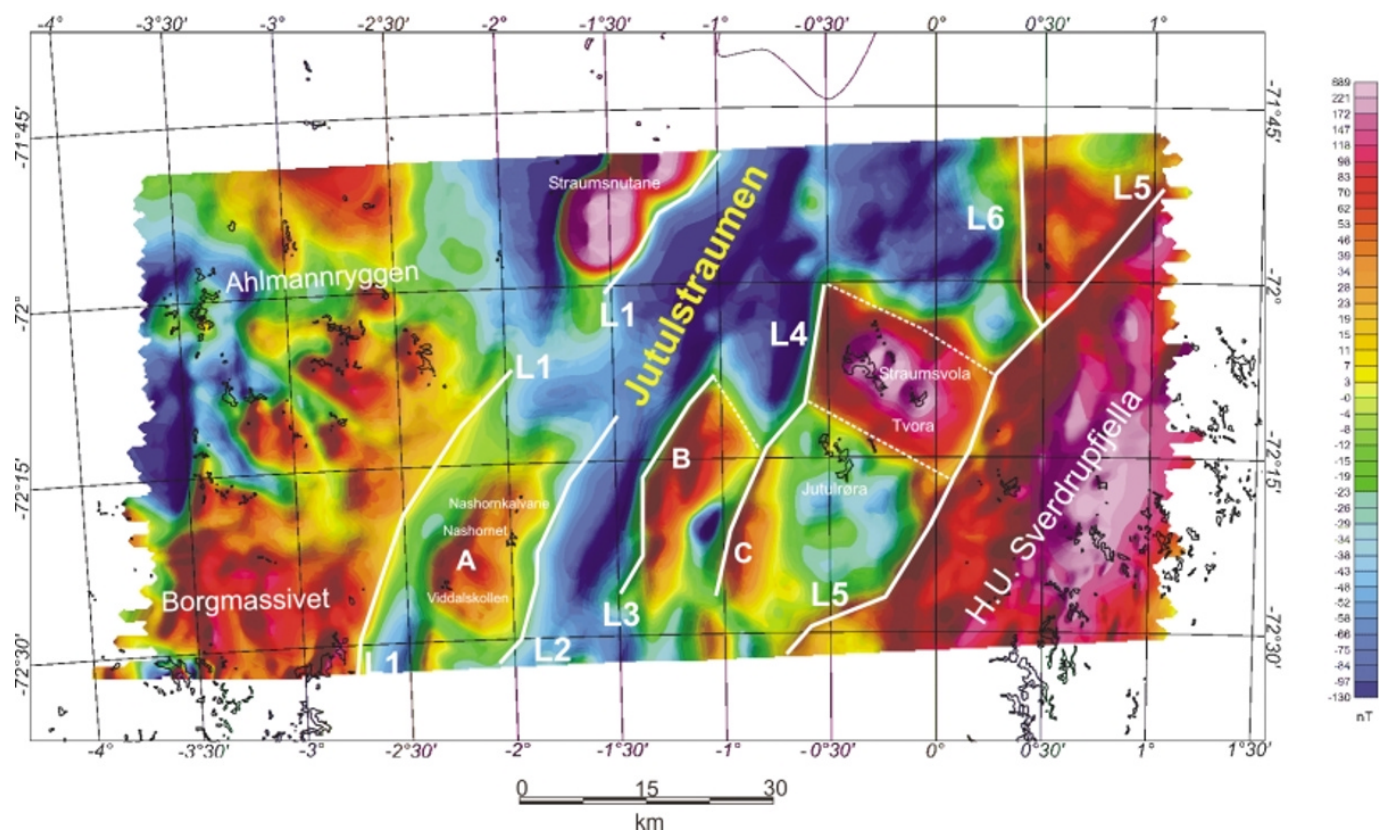

Fig. 5. Reduced to the pole aeromagnetic anomaly map. White lines show the prominent NE-SW to NNE-SSW magnetic lineaments. Dashed white lines indicate the NW-SE trend of the Straumsvola-Tvora anomaly. Major crustal blocks are readily apparent from the map. Many high-frequency magnetic trends can also be recognised, especially over the Borgmassivet and Ahlmannryggen blocks, along the western flank of the inferred Jutulstraumen rift.

and Vestfjella (Kirwanveggen Formation), and have been viewed as an Antarctic extension of the voluminous Karoo Large Igneous Province (Harris et al., 1990; Duncan et al., 1997; Luttinen and Furnes, 2000). These rocks may record the initiation of lithospheric extension in western Dronning Maud Land, focussed along the inferred margins of the Grunehonga craton (Luttinen and Furnes, 2000). In H. U. Sverdrupfjella there are no outcrops of these flood-basalts, but two Jurassic alkaline intrusions, the Straumsvola nepheline syenite complex and the Tvora quartz syenite, may relate to inferred crustal extension in the Jutulstraumen rift (Harris and Grantham, 1993). The Sistefjell syenite is located along the south-western flank of the Jutulstraumen glacier, which may be underlain by a separate branch of the inferred rift (Figs. 2 and 3). The $173 \pm 2$ Ma Sistefjell syenite intrudes a sheet of massive trachytic basalt of unknown age (Harris, 1995; Knoper et al., 1997).

Intrusion of N-S to NE-SW oriented Jurassic dykes, predates and post-dates the Straumsvola complex (Grantham and Hunter, 1991; Grantham, 1996), dated at 178 $\pm 2 \mathrm{Ma}$ (Grantham et al., 2001). Small Jurassic dolerite dyke swarms, perhaps related to the inferred Jutulstraumen rift, are relatively common throughout the entire region (Harris et al., 1991; Riley et al., 2005).

The age of extensional faulting in the inferred Jutulstraumen and Pencksökket rifts is uncertain. Faulting in the Pencksökket segment of the rift appears to post-date the Jurassic volcanism (Grantham and Hunter, 1991). Apatitefission track data over Heimenfrontfjella (Fig. 1) have been interpreted to indicate that flexural uplift and denudational cooling, related to the inferred crustal extension, occurred later at c. $100 \mathrm{Ma}$ (Jacobs and Lisker, 1999).

\section{Aeromagnetic Survey \\ 3.1 Data acquisition}

A British Antarctic Survey Twin Otter and survey team acquired 15,500 line-km of aeromagnetic data during the 2001/02 Antarctic field season along a 1-km line spacing grid with tie-lines $8 \mathrm{~km}$ apart (Figs. 4(a)-(b)). Twenty-five flights were flown from the South African base SANAE (Fig. 1), for a total of 100 survey hours. Aerogravity data were acquired simultaneously and airborne-radio echo sounding data were collected for 5 flights, to image icethickness and bedrock configurations (Fig. 4(b)). The results of the aerogravity investigation will be reported elsewhere (Ferraccioli et al., in press). The aeromagnetic data were acquired at a constant barometric altitude of $2600 \mathrm{~m}$. This provided a terrain clearance of $100 \mathrm{~m}$ over the highest peaks. The choice of a barometric survey mode was a compromise for the acquisition of reliable aerogravity data.

Geomagnetic activity prior to and during the survey was monitored with a Geometrics base station set up at the SANAE (Fig. 1), and acquired data at a 30 second sampling rate. Survey flights took place when a relatively "quiet" magnetic field could be expected (i.e. variations were typically less than $20 \mathrm{nT}$ along a line) and ensuring that filtered diurnal variations could be subtracted from the raw magnetic data during the subsequent aeromagnetic data processing. A GPS receiver (Ashtech Z-12) was used as a base station to allow for differential corrections to be applied to the positioning data. Optically pumped Cesium magnetometers (Scintrex Cs-2) were installed in wing-tip configuration, with a sampling rate of $10 \mathrm{~Hz}$. A GPS receiver (Ashtech Z-12) supplied the pseudo range data to the Picodas navigation system. 

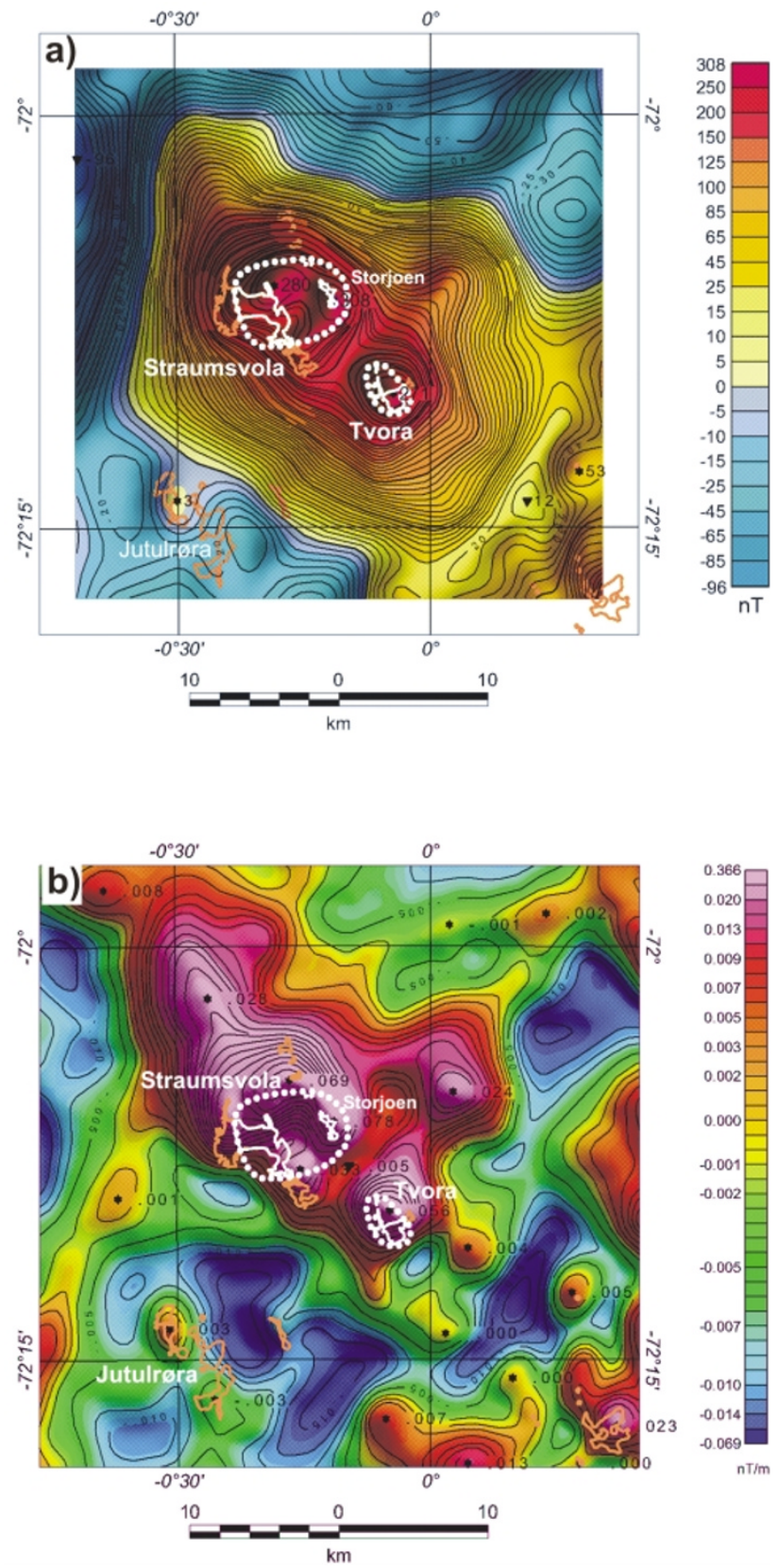

Fig. 6. a) Detail contour aeromagnetic anomaly map over the Straumsvola and Tvora regions, close to the inferred eastern flank of the Jutulstraumen rift. Stars and inverted triangles indicate relative maxima and minima of the anomalies respectively. White outline shows outcrop areas of the Jurassic alkaline intrusions of Straumsvola and Tvora (Harris and Grantham, 1993). Dotted white line indicates the inferred extent of the alkaline complexes (Curtis et al., 2003). Orange outline indicates outcrop areas of the H. U. Sverdrupfjella basement complex (Allen, 1991). Note the sharp NNE and NW-SE edges of the Straumsvola-Tvora anomaly complex; b) First vertical derivative anomaly map enhancing discrete peaks within the Straumsvola-Tvora anomaly complex and suggesting the existence of several ice-covered intrusions.

\subsection{Data processing}

After initial quality control in the field the aeromagnetic data were edited and de-spiked. Magnetic compensation procedures for aircraft motion were then performed, and heading corrections were applied. The positional data were recovered using carrier-phase, continuous, kinematic GPS processing techniques (Mader, 1992). The IGRF 2000 co- efficients were used to calculate the reference field values for each flight at the respective survey altitude. These values were then subtracted from the total field measurements. Magnetic time variations were corrected using low-pass filtered (30 minute) magnetic base station recordings. Standard deviations at cross-overs between profiles and tie lines were reduced from to $22.9 \mathrm{nT}$ to $13 \mathrm{nT}$ after base station correction. The second step in removing diurnal variation was done by minimizing the differences at the intersections of profile and tie lines. This was achieved with iterative "statistical levelling" using the program GEOSOFTOASIS. Microlevelling in frequency domain was then applied to reduce residual flight line-related corrugation (Ferraccioli et al., 1998). The overall errors at line intersections were reduced to $1.5 \mathrm{nT}$ after the complete levelling process. The resulting magnetic anomaly data were gridded using the "random gridding" minimum curvature routine of the GEOSOFT program (Briggs, 1974). The grid mesh was $250 \mathrm{~m} \times 250 \mathrm{~m}$, i.e. equal to $1 / 4$ of the line spacing. The gridded dataset was then reduced to the pole to produce a 1:250,000 magnetic anomaly map. A reduced version of the map is displayed in Fig. 5.

\section{Aeromagnetic Anomalies of the Jutulstraumen Region}

The shaded relief aeromagnetic anomaly map (Fig. 5) images a prominent NE-SW striking magnetic low over the inferred Jutulstraumen rift (Grantham and Hunter, 1991; Grantham, 1996). This linear magnetic low contrasts with the broad magnetic high over the H. U. Sverdrupfjella block, marking the inferred eastern flank of the rift. The magnetic low over the inferred Jutulstraumen rift also contrasts with the high-frequency pattern, including positive and negative magnetic anomalies, of the Borgmassivet and the Ahlmannryggen blocks. This area marks the postulated western flank of the rift. Two discrete positive anomaly complexes are located along the eastern and western side of the inferred Jutulstraumen rift: the Straumsvola-Tvora anomaly complex and the Straumsnutane anomaly. At least five major magnetic lineaments with a NE-SW to NNESSW trend (L1-L5) and a N-S trend (L6) can be defined from sharp magnetic gradients on the magnetic anomaly map over the inferred Jutulstraumen rift region.

In the following sections we analyse the magnetic anomalies in further detail by correlating the observed patterns with geology and published magnetic susceptibility measurements, where available. We start by examining magnetic signatures over the inferred Jurassic rift and then move to the postulated eastern and western flanks of the rift.

\subsection{Inferred Jutulstraumen rift}

The magnetic anomaly pattern over the inferred Jutulstraumen rift valley (Fig. 4(b)) is relatively featureless (Fig. 5). In the southern part of the survey area, a narrow, about $10 \mathrm{~km}$ wide, magnetic minimum exhibits a peak amplitude of $-80 \mathrm{nT}$. The minimum is flanked by two elongated magnetic highs with amplitudes of $60 \mathrm{nT}$ (anomaly A) and $80 \mathrm{nT}$ (anomaly B) respectively. In contrast, the northern part of the survey area features a broader magnetic low, approximately $55 \mathrm{~km}$ wide and with peak amplitude of $-120 \mathrm{nT}$. There are no outcrops within the areas of the 

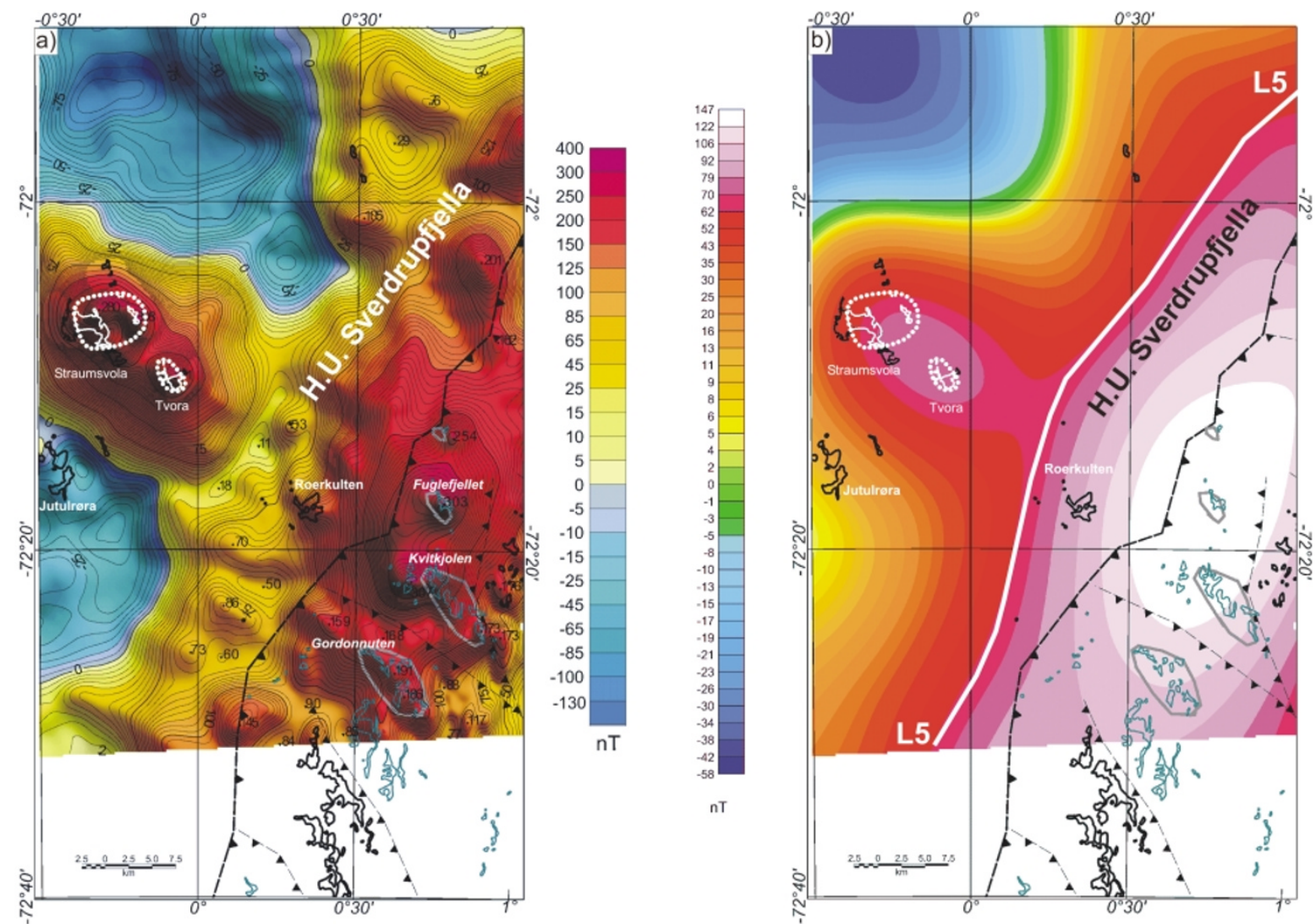

Fig. 7. a) Detail contour aeromagnetic anomaly map over the H. U. Sverdrupfjella region, along the eastern flank of the inferred Jutulstraumen rift. The high-frequency anomaly peaks super-imposed upon the broad H. U. Sverdrupfjella anomaly coincide with outcrops of the Dalmatian Granite, which is outlined in grey (Grantham et al., 1991). Black and blue outlines indicate outcrop areas of the H. U. Sverdrupfjella basement and cover rocks respectively. Other rock outcrop areas as in Fig. 6. Inferred NW-SE and NE-SW thrust faults from Allen (1991); b) Upward continued aeromagnetic anomaly map at a $10 \mathrm{~km}$ level. Note the long-wavelength component of the H. U. Sverdrupfjella anomaly, the sharp NE-SW oriented magnetic lineament L5 flanking the anomaly and the NW-SE trend of the Straumsvola-Tvora anomaly complex.

southern and northern magnetic minima. Hence correlation with surface geology is not possible. One possibility is that the minima reflect reversely magnetized rocks, e.g. Jurassic basalts of the Kirwanveggen Formation (Figs. 1 and 3), flooring the rift basins. However, rock magnetic measurements available so far over Jurassic basalt outcrops, further to the south over the Kirwanveggen, do not appear to support this hypothesis (Sergeyev, 2000). No regional magnetic low has been previously detected over the Kirwanveggen Formation basalts (Golynsky et al., 2000a, b). An alternative hypothesis is that these magnetic minima may be imaging subglacial sediments within discrete structural basins of the inferred Jutulstraumen rift. This hypothesis is attractive because linear aerogravity lows appear to mark these aeromagnetically defined basins (Ferraccioli et al., in press).

Magnetic anomaly A overlies the Viddalskollen, Nashornet, Nashorn-Kalvane nunatak group. These nunataks are formed of massive dioritic sills of the mid-Proterozoic Borgmassivet Intrusive suite, which is more extensively exposed in the Borgmassivet. Magnetic anomalies A, B and $\mathrm{C}$ are therefore interpreted as revealing the extent of basement horsts within the inferred rift. The reduced amplitude of the anomalies (e.g. anomaly A) compared to those over the Borgmassivet may reflect increased distance to source (since the topography is higher over the mountains flanking the Jutulstraumen than over the valley itself, see Fig. 4(a)).

\subsection{Eastern flank of the Jutulstraumen}

The Straumsvola-Tvora magnetic anomaly complex is located at the eastern edge of the inferred Jutulstraumen rift (Fig. 5). It can be directly correlated with the Straumsvola and Tvora alkaline complexes of Jurassic age (Harris and Grantham, 1993). The detailed contour map superimposed on the geological sketch of the area (Fig. 6(a)) shows a discrete 308 nT peak over the Storjoen nunatak, and a lower amplitude peak (280 nT) close to the Straumsvola outcrop. The Tvora nunatak is marked by a distinct $271 \mathrm{nT}$ anomaly peak. To enhance the higher-frequency components of the Straumsvola-Tvora anomaly complex we computed a first vertical derivative map for the area (Fig. 6(b)). This map displays at least six individual peaks related to shallowsource magnetic anomalies. The derivative map suggests that several intrusions may lie beneath the ice cover in the Straumsvola and Tvora areas. High mean magnetic susceptibilities (26 $10^{-3}$ SI units) have been measured on outcrops of the Straumsvola nepheline syenite complex (Sergeyev, 2000), suggesting that these alkaline rocks are indeed the source of the observed anomaly.

The Straumsvola-Tvora magnetic anomaly complex has sharp NNE and NW-SE edges. Surprisingly, the major axis of the magnetic anomaly complex trends NW-SE, i.e. almost perpendicular to the trend of the inferred Jutulstraumen rift. 


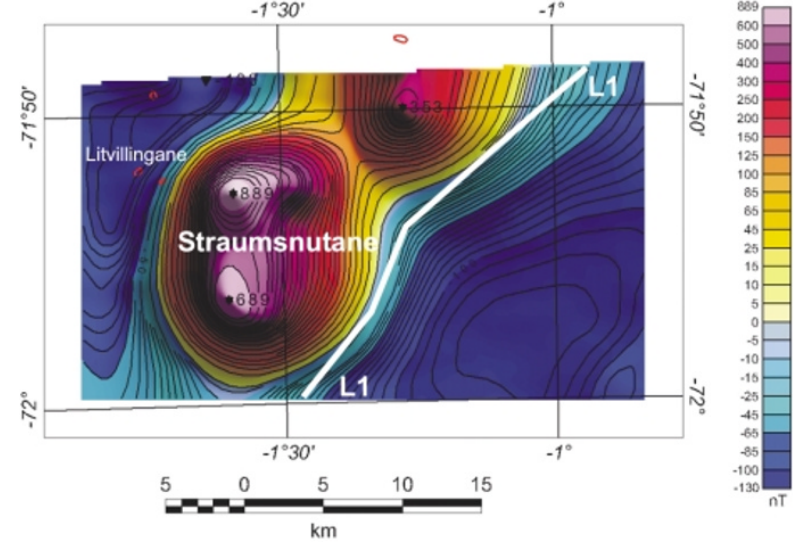

Fig. 8. Detail contour aeromagnetic anomaly map over the Straumsnutane region along the northwestern flank of the Jutulstraumen. Red outline shows outcrops of the Straumsnutane Formation. Note that the main anomaly lies east of the outcrop areas. White line is the NE-SW oriented magnetic lineament L1.

The H. U. Sverdrupfjella anomaly is located east of the Straumsvola-Tvora complex. The high-amplitude positive anomaly contrasts with the magnetic low over the adjacent Jutulrøra region. The contour map (Fig. 7(a)) reveals distinct high-frequency peaks that are superimposed upon the broad, $40 \mathrm{~km}$ wide, regional magnetic anomaly. One discrete 303 nT peak at Fuglefjellet overlies outcrops of the 470 Ma old Dalmatian Granite (Grantham et al., 1991). Similar peaks are detected over Gordonnuten, where the Dalmatian Granite also outcrops. Grantham et al. (1991) reported that these granites are biotite rich and include magnetite-bearing varieties. Hence, although susceptibility measurements are currently lacking, these rocks are potential sources for the shorter-wavelength anomalies. Some of the high-frequency anomalies trend NW-SE to NNWSSE, i.e. parallel to the thrust faults underlying the tributary glaciers, which were inferred by Allen (1991).

The long-wavelength component of the H. U. Sverdrupfjella anomaly is enhanced in the upward continued map $(10 \mathrm{~km})$ displayed in Fig. 7(b). In this presentation the NW-SE anomaly trends, which are presumably of shallower origin, disappear. However, the major NE-SW magnetic gradient (L5) located between Roerkulten and Jutulrora is enhanced. The NE-SW magnetic lineament is parallel to the trace of the major northwest verging thrust fault inferred by Allen (1991), suggesting it may relate to the thrust front itself. The long-wavelength character of the Sverdrupfjella anomaly implies that the sources of the anomaly are likely to be deep-seated. Hence the causative magnetic bodies may not necessarily correlate with surface geology. It appears however that the Grenvillian age Roerkulten granite coincides with the western edge of the broad magnetic anomaly. Grenvillian age meta-granitoids can be hypothesised as being the source of the anomalies. However, magnetic properties for the Roerkulten granite have not been measured to test this hypothesis. Only 14 samples of the Sverdrupfjella Group have been measured (Sergeyev, 2000). The ortho- and paragneisses have susceptibility values in the range 0.2 to $4.010^{-3}$ SI units, with the or- thogneisses being generally more highly magnetic (table 1 in Sergeyev, 2000). Even these higher susceptibility values are too low to account for the observed high-amplitude regional magnetic anomaly over $\mathrm{H}$. U. Sverdrupfjella. A similar magnetic anomaly further south over Kirwanveggen (Fig. 1), has been previously modelled as caused by a 10 $\mathrm{km}$ thick and highly magnetic (80 $10^{-3}$ SI units) crustal slab, dipping at shallow angle to the south, and related to thrusting within the Maudheim Province (Corner, 1994). Very high-magnetic susceptibities have been measured in the Kirwanveggen areas (30 to $44710^{-3}$ SI units). These values are not restricted to metabasites or amphibolites, but were also observed over leucocratic rocks, with abundant coarse-grained magnetite (Corner, 1994).

\subsection{Western flank of the Jutulstraumen}

The Straumsnutane anomaly complex is located along the northwestern flank of the Jutulstraumen (Fig. 5). The contour map reveals three discrete peaks within this anomaly complex (Fig. 8). The observed amplitudes are much higher (up to $889 \mathrm{nT}$ ) than over the Jurassic Straumsvola and Tvora anomaly complex (308 nT see Fig. 6(a)). However, minimum distance-to source is greater over the Straumsnutane than over Straumsvola (2 km vs. $1.5 \mathrm{~km})$. Outcrops of the Straumsnutane Formation are located at the western edge and to the north of the survey area. Some samples of these andesites are magnetic. Mean susceptibilities of $9.9710^{-3}$ SI units have been measured over these rocks (Wolmarans and Kent, 1982). However, unless the thickness of the andesites is in excess of several $\mathrm{km}$, these rocks are unlikely to account for the very high-amplitude anomaly we observed. Speculatively, the Straumsnutane anomaly complex could mark thick intrusives, (e.g. buried arc plutons) related to these andesites. However, we suggest that more highly magnetic and likely more mafic Jurassic intrusions, compared to the Straumsvola and Tvora complexes, are the sources of the Straumsnutane magnetic anomaly complex. Highamplitude aeromagnetic anomalies (as high $1500 \mathrm{nT}$ ) have been previously detected (at comparable flight elevations) over Jurassic tholeiitic gabbro intrusions at Utpostane and Muren (Luttinen et al., 1994; Golynsky et al., 2000a) in Vestfjella (Fig. 1). We infer that highly-magnetic gabbro could be buried in the Straumsnutane region. Preliminary airborne gravity data suggests the presence of a discrete high-amplitude positive gravity anomaly over the region, suggesting the presence of a dense body beneath Straumsnutane (Ferraccioli et al., in press). The aerogravity evidence is therefore consistent with our preferred aeromagnetic hypothesis for a buried Jurassic gabbro intrusion.

The Straumsnutane magnetic anomaly complex is located along a NE-SW trending magnetic lineament (L1 in Figs. 5 and 8). Notably, this magnetic lineament lies parallel to a strong planar fabric mapped over Straumsnutane with a NE-SW strike and steep dip to the E (Watters, 1972). Grantham and Hunter (1991) noted that the Stramsnutane fabric presents opposing dip directions to the $\mathrm{W}$ dipping joints over H. U. Sverdrupfjella, which may be consistent with a rift shoulder interpretation for these two areas (Ravich and Solov'ev, 1966). Perritt and Watkeys (2003) suggested that larger scale structural fabrics over 

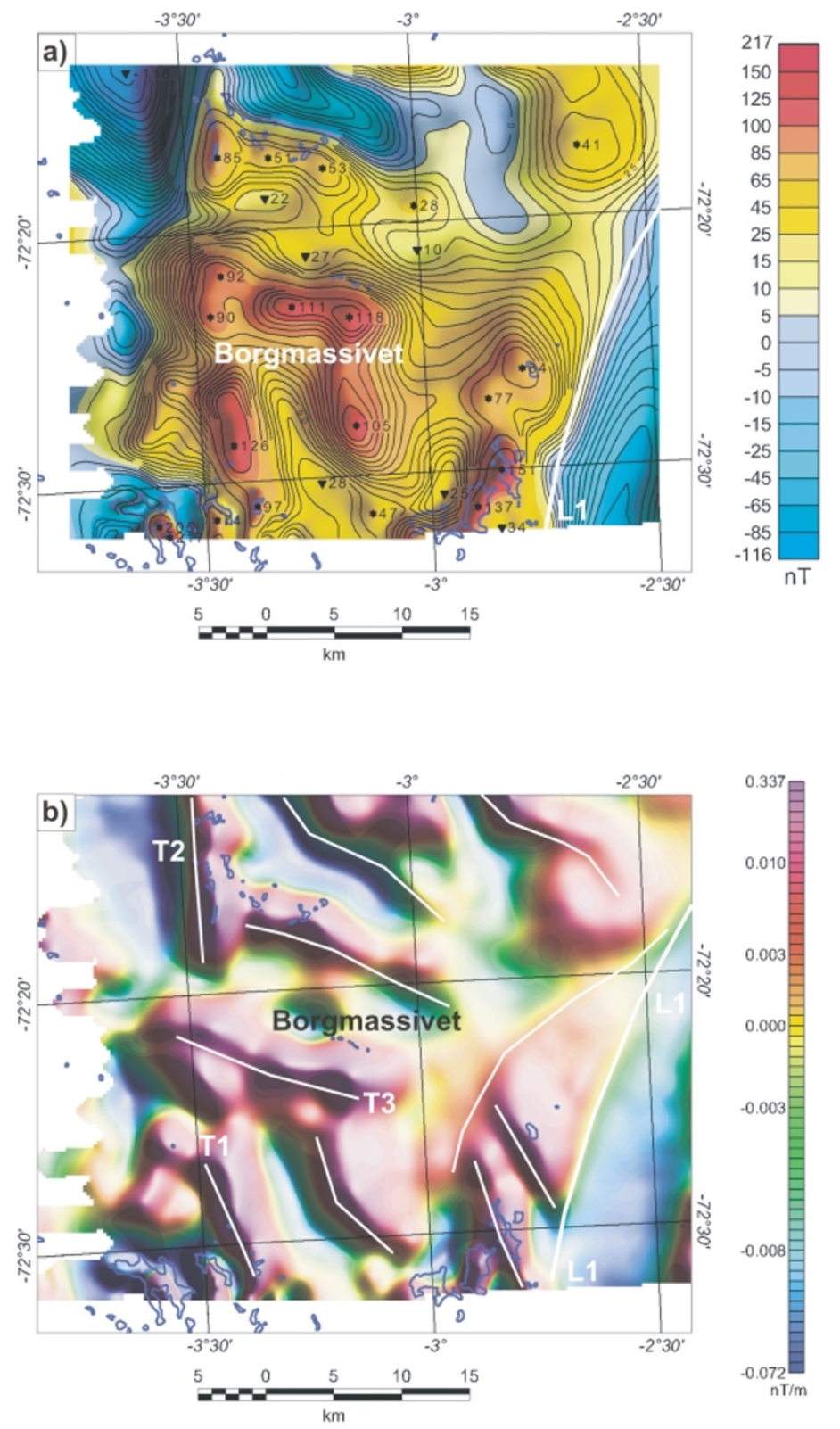

Fig. 9. a) Detail contour aeromagnetic anomaly map over the Borgmassivet region. Blue outline indicates outcrop areas of the Ahlmannryggen and Jutulstraumen Groups of the Ritscherflya Supergroup (Wolmarans and Kent, 1982). The aeromagnetic patterns delineate the largely ice-covered extent of the $1.1 \mathrm{Ga}$ (?) Borgmassivet tholeiitic sills in this area; b) First vertical derivative map enhances the high-frequency trends (white lines) within the magnetic anomaly pattern. These trends (e.g. T1, T2 and T3) are interpreted as delineating faults displacing the mid-Proterozoic sill complexes of the Borgmassivet areas, consistent with the geological interpretation of the subglacial morphology derived from radio-echo sounding data (Wolmarans and Kent, 1982).

the Straumsnutane likely relate to a regional-scale sinistralstrike slip fault zone of Cambrian age, probably extending from Straumsnutane to the Borgmassivet. Magnetic lineament L1 is interpreted as delineating this putative Cambrian strike-slip fault zone. However, clear magnetic markers to determine possible horizontal offsets are lacking. Perritt and Watkeys (2003) argued that cumulative Cambrian strike-slip offsets are regionally significant, since they lie within the $90 \mathrm{~km}$ to $300 \mathrm{~km}$ range.

The Borgmassivet area in the southwestern corner of the survey area (Fig. 9(a)) is characterised by high-frequency magnetic anomaly patterns. The anomalies have wavelengths of approximately $5 \mathrm{~km}$ and peak amplitudes in the range of -120 to $+150 \mathrm{nT}$. Magnetic susceptibility measurements (table 1 in Sergeyev, 2000) reveal that the mid-Proterozoic tholeiitic sills of the Borgmassivet Intrusives are on average highly magnetic $\left(14.210^{-3} \mathrm{SI}\right)$ in contrast to the weakly magnetic (values close to 0 ) metasedimentary rocks of the Ritscherflya Supergroup. The magnetic anomaly pattern suggests that these dolerite sill complexes are much more extensive than is apparent in outcrop. The first vertical derivative map over the area (Fig. 9(b)) enhances the trends within the high-frequency Borgmassivet anomaly pattern. At least three magnetic trend orientations can be recognised: NNW-SSE (T1), N-S (T2) and WNW-ESE (T3). These magnetic trends may delineate buried faults, displacing the sill complexes, which have been inferred to differentially tilt and uplift the 

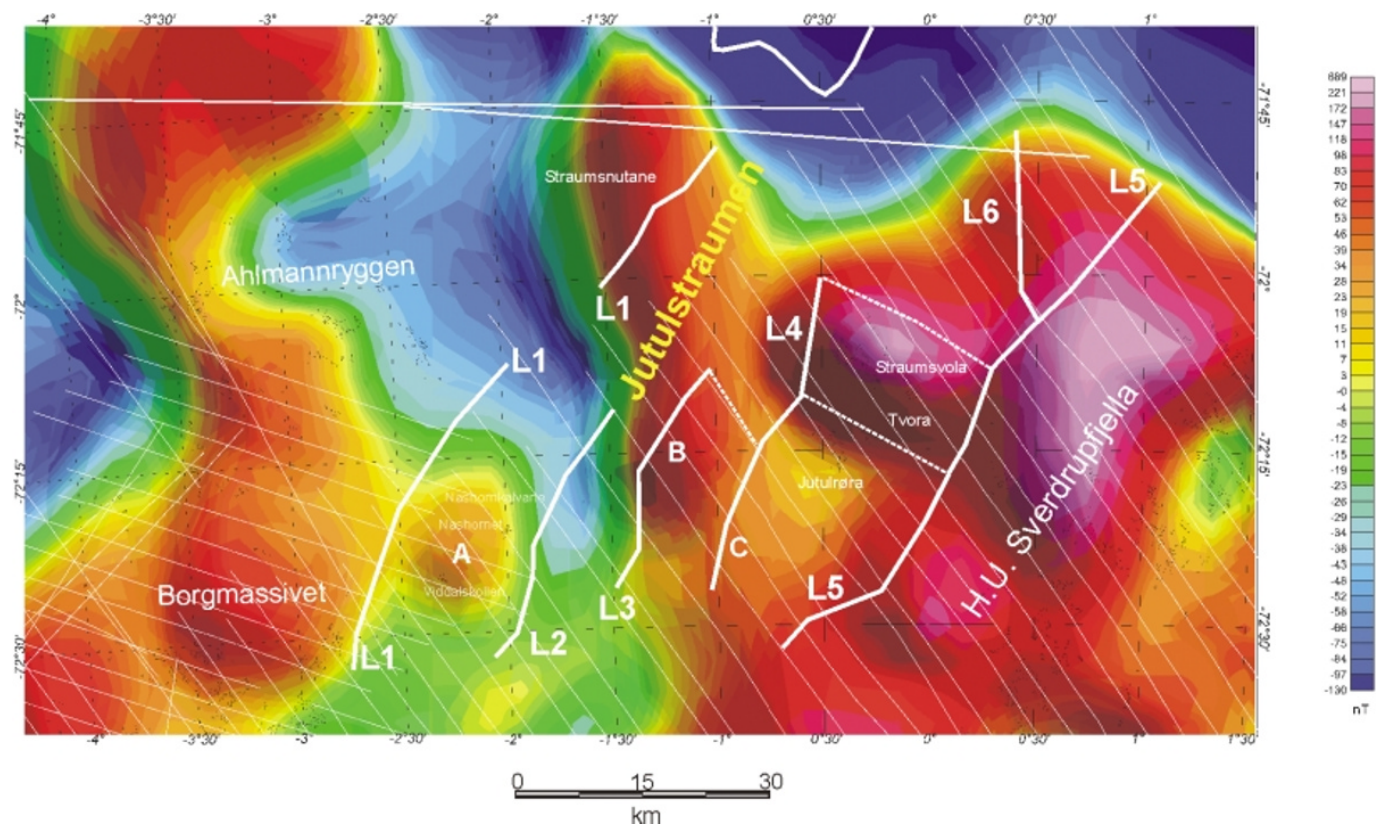

Fig. 10. Aeromagnetic anomaly image over the Jutulstraumen from the ADMAP compilation (Golynsky et al., 2001). White lines indicate the reconnaissance survey flight lines used to compile the map. Aeromagnetic lineaments as derived from our higher resolution dataset are shown as bold white lines for comparison (see Fig. 5).

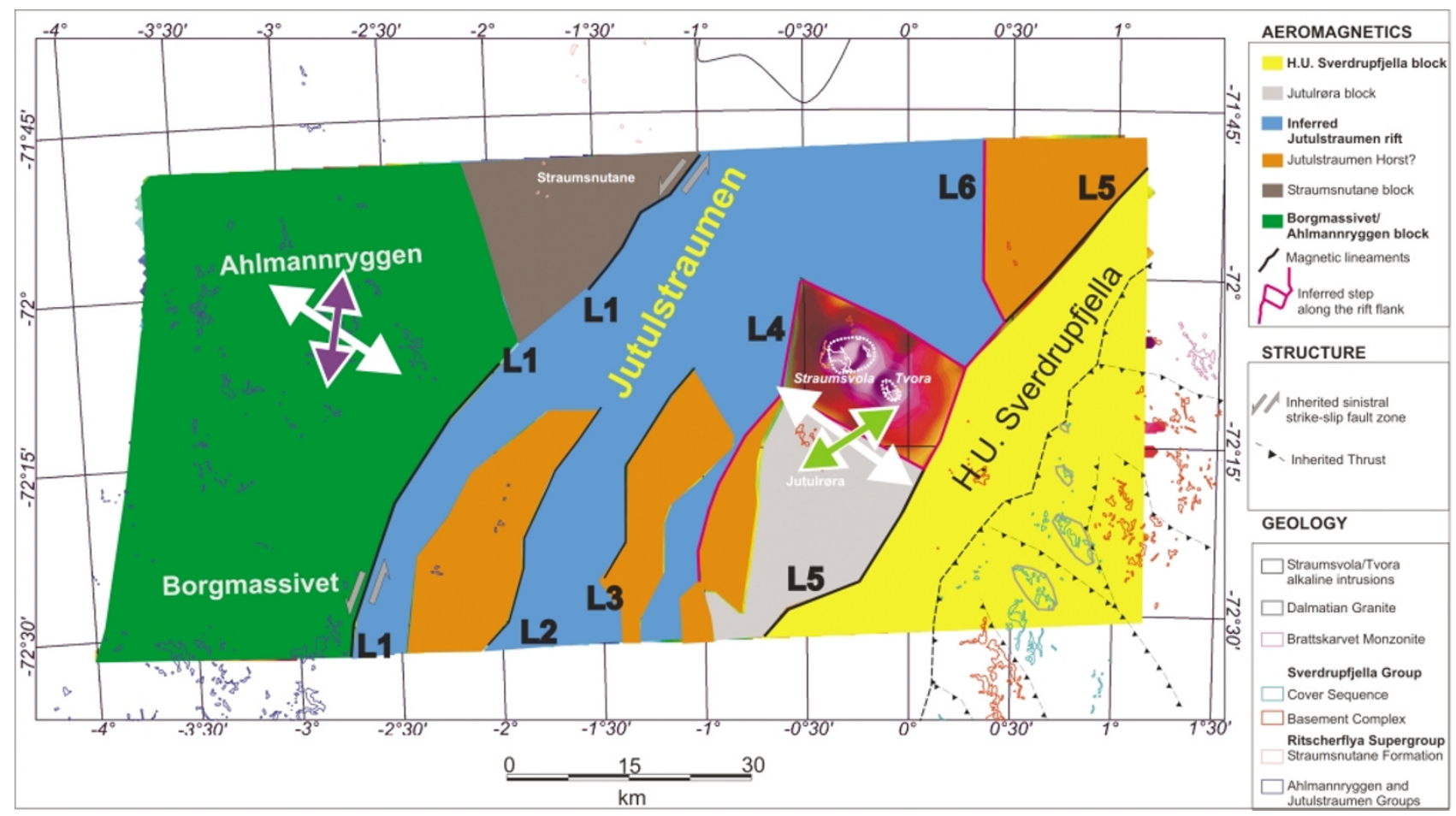

Fig. 11. Structural elements map derived by superimposing a geological sketch over the new high resolution aeromagnetic anomaly image and interpretation. The map shows the major tectonic blocks we delineated, namely the H. U. Sverdrupfjella Block, the inferred Jutulstraumen rift and the Borgmassivet/Ahlmannryggen block. Second order blocks include the Jutulrøra and the Straumsnutane blocks, and the horst blocks within the inferred rift. Magnetic lineament L1 correlates with the inferred position of a major inherited sinistral strike-slip fault of Cambrian age along the western flank of the Jutulstraumen rift (Perritt and Watkeys, 2003). A subtle magnetic gradient defines the western edge of the Straumsnutane block. Lineament L5 is located along the eastern flank of the Jutulstraumen rift and lies parallel to the major inherited Grenvillian-age thrust front (Allen, 1991). Red lines show the interpreted step along the eastern margin of the Jutulstraumen rift. Note the N-S oriented dyke dilation at $192-187$ Ma (purple arrow), which was followed by the NW-SE dilation (white arrow), between 187-178 Ma, and the ENE-WSW (green arrow) post -178 Ma dilation (Curtis et al., 2003). 
Borgmassivet block (Wolmarans and Kent, 1982).

The magnetic anomaly patterns over the Ahlmannryggen (Fig. 5) are similar to those observed over the Borgmassivet, and likely reflect mid-Proterozoic dolerite sills and probable faults displacing them. Both the BorgmassivetAhlmannryggen anomaly patterns and trends terminate abruptly against lineament L1, clearly indicating that the postulated fault along the western margin of the Jutulstraumen was active in post-mid-Proterozoic times.

\section{Interpretation and Discussion}

In Fig. 10 we show the available regional aeromagnetic coverage over the Jutulstraumen area, as derived from ADMAP (Golynsky et al., 2001). Although the previous data clearly shows the existence of the long-wavelength components of the H. U. Sverdrupfjella anomaly, comparison with the new aeromagnetic anomaly map reveals the considerable improvement in the definition of magnetic patterns and trends over the inferred Jutulstraumen rift (Fig. 5). Specific examples of this include: 1) the newly imaged NESW to NNE-SSW structural fabric, which is now evident over Jutulstraumen, as opposed to the previously imaged apparent N-S fabric; 2) the much more prominent Straumsnutane anomaly, along the western flank of the Jutulstraumen; 3) the definition of horst blocks within the Jutulstraumen; 4) the high-frequency anomalies over the H. U. Sverdrupfjella, Borgmassivet and Ahlmannryggen blocks. These examples show that even in areas where some reconnaissance aeromagnetic data is available, there is a need for high-resolution surveys for improved geological and structural interpretation over Antarctica. Higher resolution data allows us, for example, to propose more accurate kinematic interpretations by comparing aeromagnetic trends with paleo-stress indicators (see discussion).

A structural element map was compiled by superimposing the new aeromagnetic anomaly interpretation over a geological sketch map for the Jutulstraumen region (Fig. 11). This interpretative map forms the basis for our discussion. Magnetic lineaments separate the inferred Jutulstraumen rift, from the interpreted H. U. Sverdrupfjella and the Borgmassivet-Ahlmannryggen fault blocks. The NE-SW to NNE-SSW oriented magnetic lineaments flanking these blocks are interpreted as reflecting the largely icecovered Grenvillian to Pan-African-age faults (Allen, 1991; Groenwald et al., 1995; Perritt and Watkeys, 2003) located at the transition between the Grunehogna Craton and the Maudheim Province (Fig. 1).

An important issue for further discussion is whether aeromagnetic evidence supports or contradicts the presence of a later Jurassic volcano-tectonic rift zone beneath the Jutulstraumen ice stream. The quiet magnetic anomaly patterns observed over the Jutulstraumen ice stream (Fig. 5) may be interpreted to suggest the lack of magmatic complexes along the axis of the inferred Jutulstraumen rift. However, one must consider that the Jutulstraumen ice stream flows in a deep subglacial trench, reaching depths of approximately $1.5 \mathrm{~km}$ below sea level (Fig. 4(b)). This implies that magnetic anomaly sources would lie at a distance of least at $4.1 \mathrm{~km}$ from our survey altitude $(2.6 \mathrm{~km})$, even if one assumed no post-Jurassic sedimentary infill within the inferred Jutulstraumen rift. Upward continuation at a $10 \mathrm{~km}$ level (Fig. 7(b)) demonstrates, however, that major Jurassic alkaline complexes, such as those outcropping over Straumsvola and Tvora, would still be detectable beneath the deep Jutulstraumen ice stream, if they existed. Small dyke swarms (average dyke width less than $1 \mathrm{~m}$ ) which outcrop in the Straumsvola and Tvora areas (Grantham et al., 1996; Riley et al., 2005) are not discernible in our $1 \mathrm{~km}$ line-spacing and barometric mode survey flown at $2.6 \mathrm{~km}$ above sea level. This was verified also by inspection of the higher resolution (6-7 metres) profile data (not shown here). Consequently, our data cannot be used to argue against similar minor Jurassic dyke swarms buried beneath the Jutulstraumen ice stream. Major Jurassic dyke swarms, such as the Botswana-Okavango dyke swarm (Fig. 2), which has a remarkable aeromagnetic signature over South Africa (Reeves, 2000; Marsh, 2002), are not readily apparent from our aeromagnetic data over the Jutulstraumen.

The quiet negative magnetic anomaly patterns over the Jutulstraumen resemble those observed further south over the Pencksökket branch (Figs. 1 and 2) of the inferred Jurassic rift system (Golynsky et al., 2000a). Golynsky et al. (2000b) interpreted the quiet negative magnetic anomaly patterns over the Pencksökket glacier as indicating that the axis of the inferred Jurassic rift underlying the glacier was largely amagmatic. This interpretation could also apply to our higher resolution observations over the inferred Jutulstraumen rift segment. The aeromagnetic hypothesis for a weakly magmatic Jurassic rift basin beneath the Jutulstraumen would contrast with the strongly magmatic rifts represented by the Jurassic Lebombo monocline in Africa and the Explora rift (Fig. 2(b)) in offshore Dronning Maud Land (Cox, 1992; Jokat et al., 2003), which feature highamplitude positive magnetic anomalies. The inferred Jutulstraumen rift basin appears to lack high-amplitude positive aeromagnetic anomalies typically observed for example over highly magmatic subglacial rift basins of the Cenozoic West Antarctic Rift System (Behrendt et al., 1996; Behrendt, 1999).

An additional hypothesis, that could account for the quiet, negative magnetic anomaly patterns over the Jutulstraumen is that they reflect the presence of post-Jurassic (?) sediments within the inferred Jutulstraumen rift. A well-known Antarctic example of a prominent linear aeromagnetic low over a narrow rift, containing thick sedimentary infill, is the Cenozoic Terror Rift (Behrendt et al., 1996 and refs. therein), within the Ross Sea Rift (inset in Fig. 1). Jacobs and Lisker (1999) proposed that Cretaceous and Cenozoic erosional detritus from the Heimefrontfjella horst (Fig. 1) could have been channelled into the inferred Pencksökket and Jutulstraumen rifts. The aerogravity lows detected over the Jutulstraumen rift (Ferraccioli et al., in press) will be modelled to test the aeromagnetic hypothesis presented here for possible sedimentary infill within the inferred Jutulstraumen rift.

In contrast to a rift hypothesis (Grantham and Hunter, 1991; Golynsky1 et al., 2000a, b) for the structures underlying the subglacial troughs of western Dronning Maud Land, Corner (1994) modelled regional aeromagnetic data together with land-gravity data to show that the Pencksökket 
glacier could simply be underlain by fossil thrust faults in the basement. Corner (1994) further used the regional aeromagnetic data to identify two generations of thrust faults over the Kirwanveggen-Pencksökket areas (Fig. 3) and interpreted at least one of them as being Pan-African in age. Our more detailed aeromagnetic maps over the H. U. Sverdrupfjella (Figs. 7(a), (b)) also suggest that that both the NE-SW and NW-SE aeromagnetic trends could relate to inferred thrust faults within the Maudheim Province (Allen, 1991; Groenwald et al., 1995). The 470 Ma Dalmatian Granite (Grantham et al., 1991) could also be spatially associated with some of the inferred NE-SW thrust faults (Fig. 7(a)). Over the Straumsnutane (Fig. 8) and Borgmassivet (Fig. 9(a)) areas aeromagnetic lineament L1 is coincident with the proposed location of a major left-lateral strikeslip fault, which may have induced transpression and associated thrusting over the H. U. Sverdrupfjella block at about $520 \mathrm{Ma}$ (Perritt and Watkeys, 2003).

These aeromagnetic observations prompt the question of whether the Jutulstraumen ice stream is simply underlain by fossil Pan-African age structures, or whether Jurassic reactivation occurred. Recent geological observations, along with the new aeromagnetic data presented here, suggest that the Jutulstraumen was a region of active extension in the Jurassic. A complex set of palaeo-dilation directions has recently been determined from the relatively minor Jurassic dyke swarms in the Ahlmannryggen, Straumsvola and Jutulrøra areas (Curtis et al., 2003; Riley et al., 2005). Initial N-S oriented dyke dilation (purple arrow in Fig. 11) in the Ahlmannryggen, between 192-187 Ma, was followed by NW-SE oriented dilation between 187-178 Ma (white arrow), and a post 178 Ma phase of ENE-WSW directed dilation (green arrow), recognised in the Straumsvola area. Evidence for NW-SE dilation is present within dyke swarms on both sides of the Jutulstraumen (Fig. 11). This suggests dyke emplacement in response to a regionally imposed NW-SE minimum principal stress direction between 187-178 Ma. The NW-SE minimum principal stress direction is perpendicular to the strike of the inferred Jutulstraumen rift structure, delineated by aeromagnetic lineaments L1-L2-L3 and L5 (Figs. 5 and 11). However, one of the most striking results of the aeromagnetic survey is the NWSE trend of the Straumsvola and Tvora anomaly complex (Figs. 6(a)-(b) and 11), which is highly oblique to the trend of the inferred Jurassic rift. The anomaly complex appears to lie parallel, rather than perpendicular to the minimum principal stress direction, revealed from Jurassic dykes and syntectonic fabrics within the Straumsvola pluton. We interpret magnetic lineaments L4-L5 and L6, coupled with the NW-SE trends of the Straumsvola-Tvora anomaly complex, to suggest a more complex structure compared to a simple linear Jurassic rift. We infer that the NW-SE trend could image a jog or a transfer fault zone close to the eastern flank of the inferred Jurassic rift (Fig. 11). We speculate that this transverse structure may have controlled the location of the rift-related mid-Jurassic alkaline complexes (Harris and Grantham, 1993). Notably the NW-SE trend of the Straumsvola-Tvora anomaly is parallel to the trends of some of the thrust faults inferred in H. U. Sverdrupfjella, suggesting that the inherited structures may have played an important role in localising the Jurassic alkaline intrusions.

\section{Conclusions}

We have presented some results of a high-resolution aeromagnetic anomaly investigation carried over the Jutulstraumen ice stream, western Dronning Maud Land. These results are summarised below:

1) Prominent NE-SW oriented magnetic lineaments are imaged in the Jutulstraumen region. These lineaments may reflect the inherited Pan-African and Grenvillian age faults of the Maudheim Province and the later structural fabric of the inferred Jutulstraumen rift.

2) A broad magnetic anomaly over H. U. Sverdrupfjella marks the eastern flank of the inferred Jutulstraumen rift. It may be caused by buried Grenvillian-age rocks. However, the higher-frequency anomalies relate to the Pan-African age Dalmatian granite, which appears to be spatially associated with NW-SE oriented thrust faults.

3) The Straumsvola-Tvora anomaly complex correlates with mid-Jurassic alkaline intrusions. These intrusions appear to be located within a jog or perhaps or transfer fault close to the eastern flank of the inferred Jutulstraumen rift.

4) The inferred western flank of the Jutulstraumen rift is dominated by high-frequency magnetic anomalies delineating mid-Proterozoic tholeiites of the Borgmassivet and Ahlmannryggen areas. A discrete highamplitude magnetic anomaly complex at Straumsnutane may reveal a mafic intrusion, perhaps of Jurassic age.

5) The quiet magnetic anomaly pattern over the Jutulstraumen ice stream suggests that the inferred rift was not a focus for voluminous magmatism during Jurassic regional extension, and/or that subglacial sediments are present within the inferred rift basin.

Acknowledgments. This paper is a contribution to the MAMOG project of the British Antarctic Survey. Constructive reviews by Ash Johnson and Vicki Langenheim improved the MS. The authors wish to thank staff at the South African base for their support during the aeromagnetic survey. We gratefully acknowledge the Engineering and Technical Services staff of BAS for their assistance during aeromagnetic data acquisition. The BAS pilot David Leatherdale is thanked for his dedication in flying the survey. Hugh Corr of the BAS aerogeophysics team is thanked for providing radar data to compile the ice thickness grid over the Jutulstraumen area.

\section{References}

Allen, A. R., The tectonic and metamorphic evolution of H. U. Sverdrupfjella, western Dronning Maud Land, Antarctica, in Geological evolution of Antarctica, edited by M. R. A. Thomson, J. A. Crame, and J. W. Thomson, pp. 53-60, Cambridge University Press, Cambridge, 1991.

Barton, J. M., R. Klemd, H. L. Allssop, S. H. Auret, and Y. E. Copperthwaite, The geology and geochronology of the Annandagstoppane granite, western Dronning Maud Land, Antarctica, Contributions to Mineralogy and Petrology, 97, 488-496, 1987.

Behrendt, J. C., Crustal and lithospheric structure of the West Antarctic Rift System from geophysical investigations-a review, Global and 
Planetary Change, 23, 25-44, 1999.

Behrendt, J. C., R. Saltus, D. Damaske, A. McCafferty, C. A. Finn, D. Blankenship, and R. E. Bell, Patterns of late Cenozoic volcanic and tectonic activity in the West Antarctic rift system revealed by aeromagnetic surveys, Tectonics, 15, 660-676, 1996.

Blankenship, D., R. E. Bell, S. M. Hodge, J. M. Brozena, J. C. Behrendt, and C. A. Finn, Active volcanism beneath the West Antarctic ice sheet and implications for ice-sheet stability, Nature, 361, 526-529, 1993.

Bozzo, E., D. Damaske, G. Caneva, M. Chiappini, F. Ferraccioli, M. Gambetta, and A. Meloni, A high resolution aeromagnetic survey over proposed drill sites offshore of Cape Roberts in the Southwestern Ross Sea (Antarctica), in The Antarctic Region: Geological Evolution and Processes, edited by C. A. Ricci, pp. 1129-1133, Terra Antartica Publication, Siena, 1997.

Briggs, J. C., Machine contouring using minimum curvature, Geophysics, 39, 39-48, 1974.

Corner, B., Geological evolution of western Dronning Maud Land within a Gondwana framework: geophysics subprogramme, Final Project Report to SACAR, 1994.

Cox, K. G., Karoo igneous activity and the early stages of the break-up of Gondwanaland, in Magmatism and the Causes of Continental Breakup, edited by B. C. Storey, T. Alabaster, and R. J. Pankhurst, Geol. Soc. Spec. Publ., 68, 137-148, 1992.

Curtis, M. L., T. R. Riley, P. T. Leat, and F. Ferraccioli, Tectonic inferences from Jurassic dyke swarms and alkaline pluton emplacement in western Dronning Maud Land, Paper presented at 9th International Symposium on Antarctic Earth Sciences, 8-12 Sept. 2003, Potsdam, Germany, Terra Nostra, 60-61, 2003.

Duncan, R. A., P. R. Hooper, J. Rehacek, J. S. Marsh, and A. R. Duncan, The timing and duration of the Karoo igneous event, southern Gondwana, Journal of Geophysical Research, 102, 18127-18138, 1997.

Ferraccioli, F. and E. Bozzo, Inherited crustal features and tectonic blocks of the Transantarctic Mountains: an aeromagnetic perspective (Victoria Land-Antarctica), Journal of Geophysical Research, 104, 25,29725,319, 1999.

Ferraccioli, F. and E. Bozzo, Cenozoic strike-slip faulting from the eastern margin of the Wilkes Subglacial Basin to the western margin of the Ross Sea Rift: an aeromagnetic connection, in Intraplate Strike-Slip Deformation Belts, edited by F. Storti, R. E. Holdsworth, and F. Salvini, Geol. Soc., London, Spec. Pub., 210, 109-133, 2003.

Ferraccioli, F., M. Gambetta, and E. Bozzo, Microlevelling procedures applied to regional aeromagnetic data: an example from the Transantarctic Mountains (Antarctica), Geophysical Prospecting, 46, 177-196, 1998.

Ferraccioli, F., E. Bozzo, and G. Capponi, Aeromagnetic and gravity anomaly constraints for an early Paleozoic subduction system of Victoria Land, Antarctica, Geophys. Res. Lett., 29(10), 1406, doi:10.1029/ 2001GL014138, 2002a.

Ferraccioli, F., E. Bozzo, and D. Damaske, Aeromagnetic signatures over western Marie Byrd Land provide insight into magmatic arc basement, mafic magmatism and structure of the eastern Ross Sea Rift flank, Tectonophysics, 347, 139-165, 2002b.

Ferraccioli, F., P. C. Jones, M. L. Curtis, and P. T. Leat, Subglacial imprints of early Gondwana break-up as identified from high resolution aerogeophysical data over western Dronning Maud Land, East Antarctica, Terra Nova (in press).

Finn, C., D. Moore, D. Damaske, and T. Mackey, Aeromagnetic Legacy of early Paleozoic subduction along the Pacific margin of Gondwana, Geology, 27, 1087-1090, 1999.

Golynsky, A. V. and N. D. Aleshkova, Regional magnetic anomalies of the Weddell Sea Region and their geological significance, Polarforshung, 67, 101-117, 2000a.

Golynsky, A. V., G. E. Grikurov, and E. N. Kamenev, Geological significance of regional magnetic anomalies in Coats Land and western Dronning Maud Land, Polarforshung, 67, 91-99, 2000b.

Golynsky, A. V., M. Chiappini, D. Damaske, F. Ferraccioli, J. Ferris, C. Finn,. M. Ghidella, T. Isihara, A. Johnson, S. Kovacs, V. Masolov, Y. Nogi, M. Purucker, P. Taylor, and M. Torta, ADMAP-Magnetic anomaly map of the Antarctic, 1:10,000 scale map. BAS (Misc.) 10, Cambridge, British Antarctic Survey, 2001.

Golynsky, A. V., P. Morris, L. C. Kovacs, and J. K. Ferris, A new magnetic map of the Weddell Sea and the Antarctic Peninsula, Tectonophysics, 347, 3-11, 2002.

Golynsky, A. V., M. Chiappini, D. Damaske, F. Ferraccioli, C. Finn, T. Ishihara, V. N. Masolov, P. Morris, Y. Nogi, and R. R. B. von Frese, ADMAP - a Digital Magnetic Anomaly Map of the Antarctic, paper presented at 9th International Symposium on Antarctic Earth Sciences, 8-12 Sept. 2003, Potsdam, Germany, Terra Nostra, 123-124, 2003.

Grantham, G. H., Aspects of Jurassic magmatism and faulting in western Dronning Maud Land, Antarctica: implications for Gondwana breakup, in Weddell Sea Tectonics and Gondwana Break-up, edited by B. C. Storey, E. C. King and R. A. Livermore, Geol. Soc. Spec. Publ., 108, 63-73, 1996.

Grantham, G. H. and D. R. Hunter, The timing and nature of faulting and jointing adjacent to the Pencksökket, western Dronning Maud Land, Antarctica, in Geological Evolution of Antarctica, edited by M. R. A. Thomson, J. A. Crame, and J. W. Thomson, pp. 47-51, Cambridge University Press, Cambridge, 1991.

Grantham, G. H., P. B. Groenwald, and D. R. Hunter, Geology of the northern H. U. Sverdrupfjella, western Dronning Maud Land and the implications for Gondwana reconstructions, South African Journal of Antarctic Research, 18, 2-10, 1988.

Grantham, G. H., A. B. Moyes, and D. R. Hunter, The age, petrogenesis and emplacement of the Dalamatian granite, H. U. Sverdrupfjella, Dronning Maud Land, Antarctica, Antarctic Science, 3, 197-204, 1991. Grantham, G. H., C. Jackson, A. B. Moyes, P. B. Groenwald, P. D. Harris, G. Ferrar, and J. R. Krynauw, The tectonothermal evolution of the Kirwanveggen-H. U. Sverdrupfjella areas, Dronning Maud Land, Antarctica, Precambrian Research, 75, 200-231, 1995.

Grantham, G. H., P. G. Guise, T. Spell, B. M. Eglington, and F. J. Kruger, The age, chemistry and structure of Jurassic intrusions in H. U. Sverdrupfjella, western Dronning Maud Land, Paper presented at IV International Dyke Conference, Ithala, South Africa, 27, 2001.

Groenwald, P. B., G. H. Grantham, and M. K. Watkeys, Geological evidence for a Proterozoic to Mesozoic link between southeastern Africa and Dronning Maud Land, Antarctica, J. Geol. Soc., London, 148, 1115-1123, 1991.

Groenwald. P. B., A. B. Moyes, G. H. Grantham, and J. R. Krynauw, East Antarctic crustal evolution: geological constraints and modelling in western Dronning Maud Land, Antarctica, Precambrian Research, 75, 231-251, 1995.

Hanson, R. E., M. W. Martin, S. A. Bowring, and H. Munyanyiwa, U$\mathrm{Pb}$ zircon age for the Umkondo dolerites, eastern Zimbabwe: $1.1 \mathrm{Ga}$ large igneous province in southern Africa-East Antarctica and possible Rodinia correlations, Geology, 26, 1143-1146, 1998.

Harris, C., Petrogenesis of the Sistfjell syenite complex, Dronning Maud Land: generation of low $\delta^{18} \mathrm{O}$ magmas by crustal contamination of rift zone magmas, Geological Society of South Africa Centennial Geocongress, Extended Abstracts, 1, 240-243, 1995.

Harris, C. and G. H. Grantham, Geology and petrogenesis of the Straumsvola nepheline syenite complex, Dronning Maud Land, Antarctica, Geological Magazine, 130, 513-532, 1993.

Harris, C., J. S. Marsh, A. R. Duncan, and A. J. Erlank, The petrogenesis of the Kirwan Basalts of Dronning Maud Land, Antarctica, Journal of Petrology, 31, 341-369, 1990.

Harris, C., B. R. Watters, and P. B. Groenewald, Geochemistry of the Mesozoic regional basic dykes of western Dronning Maud Land, Antarctica, Contributions to Mineralogy and Petrology, 107, 100-111, 1991.

Hoyday, $\varnothing$. A., A force balance study of ice flow and basal conditions of Jutulstraumen, Antarctica, Journal of Glaciology, 42, 413-425, 1996.

Jacobs, J. and F. Lisker, Post-Permian tectono-thermal evolution of western Dronning Maud Land, East Antarctica: an apatite-fission track approach, Antarctic Science, 11(4), 451-460, 1999.

Jokat, W., T. Boebel, M. König, and U. Meyer, Timing and geometry of early Gondwana breakup, J. Geophys. Res., 108(B9), 2428, doi:10.1029/2002JB001802, 2003.

Knoper, M., C. Jackson, P. Harris, G. Ferrar, J. Krynauv, A. Moyes, and C. Harris, Geological maps of the Kirwanveggen, western Dronning Maud Land, East Antarctica, in The Antarctic Region: Geological Evolution and Processes, edited by C. A. Ricci, pp. 1129-1133, Terra Antartica Publication, Siena, 1997.

Luttinen, A. V. and H. Furnes, Flood basalts of Vestfjella: Jurassic magmatism across an Archaean-Proterozoic lithospheric boundary in Dronning Maud Land, Antarctica, Journal of Petrology, 41, 1271-1305, 2000.

Luttinen, A. V., K. H. Grind, J. U. Siivola, and M. H. Räisänen, The mafic igneous rocks of Vestfjella, western Dronning Maud Land, Antarctica, Antarctic Rep. Finland, 4, 12-19, 1994.

Mader, G. L., Rapid static and kinematic Global Positioning System solutions using the ambiguity function technique, J. Geophys. Res., 97, 
3271-3283, 1992.

Marsh, J. S., Discussion "The geophysical mapping of Mesozoic dyke swarms in southern Africa and their origin in the disruption of Gondwana", J. African Earth Sci., 35, 525-527, 2002.

Martin, A. K. and C. J. H. Hartnady, Plate tectonic development of the south west Indian Ocean: a revised reconstruction of East Antarctica and Africa, J. Geophys. Res., 91, 4767-4786, 1986.

Moyes, A. B., J. M. Barton, and P. B. Groenewald, Late Proterozoic to Early Palaeozoic tectonism in Dronning Maud Land, Antarctica: supercontinental fragmentation and amalgamation, J. Geol. Soc., London, 150, 833-842, 1993a.

Moyes, A. B., P. B. Groenwald, and R. W. Brown, Isotopic constraints on the age and origin of the Brattskarvet intrusive suite, Dronning Maud Land, Antarctica. Chemical Geology, 106, 453-466, 1993 b.

Perritt, S. H. and M. K. Watkeys, Implications of late Pan-African shearing in western Dronning Maud Land, Antarctica, in Intraplate strike-slip Deformation Belts, edited by F. Storti, R. E. Holdsworth, and F. Salvini, Geol. Soc., London, Spec. Pub., 210, 135-143, 2003.

Ravich, M. G. and D. S. Solov'ev, Geology and petrology of the mountains of central Queen Maud Land (Eastern Antarctica), Transactions of the Science Research Institute of Arctic Geology, Ministry of Geology of the USSR, 141, 348 pp., 1966.
Reeves, C., The geophysical mapping of Mesozoic dyke swarms in southern Africa and their origin in the disruption of Gondwana,

Riley, T. R., P. T. Leat, M. L. Curtis, L. L. Millar, R. A. Duncan, and A. Fazel, Early-Middle Jurassic dolerite dykes from western Dronning Maud Land (Antarctica): identifying mantle sources in the Karoo large igneous province, Journal of Petrology, 46, 1489-1524, 2005.

Sergeyev, M. B., Magnetic properties of rocks from the south-eastern part of the Weddell Sea region, Antarctica, Polarforshung, 67, 119-124, 2000.

Tikku, A. A., K. M. Marks, and L. C. Kovacs, An early Cretaceous extinct spreading center in the northern Natal valley, Tectonophysics, 347, 87108, 2002.

Watters, B. R., The Straumsnutane Volcanics, western Dronning Maud Land, Antarctica, South African Journal of Antarctic Research, 2, 23 31, 1972.

Wolmarans, L. G. and L. E. Kent, Geological investigations in western Dronning Maud Land, Antarctica-a synthesis, South African Journal of Antarctic Research, Supplement 2, 93 pp., 1982.

F. Ferraccioli (e-mail: ffe@bas.ac.uk), P. C. Jones, M. L. Curtis, P. T. Leat, and T. R. Riley 